\title{
Ranking State Fiscal Structures using Theory and Evidence
}

\author{
by \\ Neil Bania \\ Department of Planning, Public Policy and Management \\ University of Oregon \\ Eugene, OR 97403 \\ (541-346-3704, bania@uoregon.edu) \\ Joe A. Stone \\ Department of Economics \\ University of Oregon \\ Eugene, OR 97403 \\ (541-346-4663, jstone@uoregon.edu)
}

\section{University of Oregon Working Paper \\ June 2007 \\ V13}

\begin{abstract}
This paper offers unique rankings of the extent to which fiscal structures of U.S. states contribute to economic growth. The rankings are novel in two key respects: they are well grounded in established growth theory, in which the effect of taxes depends both on the level of taxes and on the composition of expenditures; and they are derived from actual estimates of the link between fiscal structures and economic growth. Estimates for the latter yield a growth hill, in which the incremental effect of taxes spent on productive services and infrastructure initially rises, reaches a peak, and then declines. Rankings derived from these estimates differ sharply from typical rankings based on levels of taxation alone. Two hypothetical policy experiments highlight both the growth-hill effects of tax investments in productive services and infrastructure and the short- and long-term tradeoffs in attempting to fund strong social services.
\end{abstract}

JEL Categories: H2, H4, H7, E62

The authors wish to thank Tim Bartik, Richard Disney, Randall Eberts, Norman Gemmell, Jo Anna Gray, Laura Leete, as well as participants in workshops at the University of Nottingham, the W.E. Upjohn Institute, and the University of Oregon for helpful comments. 


\section{Introduction}

Taxes lie at the heart of American politics and public policy - beginning with the Stamp Act and Boston Tea Party, which helped to ignite the American Revolution, and the Whiskey Rebellion, which posed an early challenge to George Washington’s presidency, and continuing with more recent state tax limitation measures. It is no surprise, then, that popular, policy, and academic interest in taxes - whether they are too high or too low and how they affect a region's prosperity - is both intense and longstanding. Would tax cuts, for example, stimulate state and local economies, as often argued, or, alternatively, would tax increases spent on education, training, public safety, and roads and bridges stimulate economic growth, as argued by others? This debate is voluminous; even listing the numerous studies of taxes is impossible here. So, what can we hope to add?

This paper offers a set of unique rankings of the extent to which fiscal structures of U.S. states (and their localities) contribute to long-term economic growth. In our analysis, we measure growth as the inflation-adjusted percentage growth in per-capita personal income. The rankings are novel in two key respects: they are grounded in established growth theory, where the effect of taxes depends both on the level of taxes and on the composition of expenditures; and they are derived from actual estimates of the link between fiscal structures and economic growth. Estimates for the latter yield a "growth hill," in which the incremental effect of taxes spent on productive services and infrastructure initially rises, reaches a peak, and then declines.

There are many rankings of state taxes and, in some instances, expenditures. The U.S. Census Bureau reports state and local taxes annually, along with the rankings by state. These reports are widely reported in the press at the national, state, and local levels, with keen interest in individual states in how their taxes compare to other states and whether they have moved up 
or down in the rankings. These and related data are also widely distributed, adapted, and augmented by various policy centers, including the Tax Policy Center, a joint venture of the Urban Institute and the Brookings Institution, the Tax Foundation, a conservative-oriented tax research group, and the Center on Budget and Policy Priorities, a liberal-oriented budget policy research center. All three are based in Washington, DC.

However, these rankings beg the question of how state fiscal structures rank in terms of their contribution or hindrance to economic growth. Addressing that question requires both that the measures used to construct the rankings be grounded in established theory of economic growth and that the rankings be calculated based on empirical estimates of the linkages between state fiscal structures and growth. The former is critical because the impact of taxes on growth depends theoretically both on the level of taxes and on where the tax revenues are spent (e.g, as in Barro 1990 and Barro and Sala-i-Martin 1992). That is, the impact of additional tax revenue differs depending on whether taxes are initially low or high and on whether the revenues are spent on redistributive, consumption-oriented programs or on public services and infrastructure that contribute directly to economic growth. The latter, i.e., that the actual rankings be calculated based on empirical estimates, is critical to ensuring that the rankings actually reflect the differential impacts of state fiscal structures on economic growth.

No study, to our knowledge, has attempted to construct rankings of state fiscal structures that account for both these factors. A number of rankings have attempted to broaden the linkages to economic growth by incorporating other elements viewed as important to a state's business climate (e.g., composition of public expenditures or regulatory environment), but even these account for neither the potential non-monotonic (i.e., growth hill) effect of taxes nor the actual empirical linkages to state economic growth. Of course, there are numerous studies of the latter, 
i.e., effects of taxes on growth, but these estimates are not used to compare individual state fiscal structures. Many of these tax studies are summarized by Poot (2000). Most studies report estimates for the effect of taxes on growth that are either insignificant or negative - though a small number are positive (e.g., Helms 1985, Mofidi and Stone 1990, and Bleaney et al. 2001). Similarly, estimates of the effects of government investment expenditures on economic growth also tend to be insignificant, though some studies find positive effects, particularly for expenditures on physical infrastructure and education (e.g., Cohen and Paul 2004 and Pereira 2000).

Barro-style models of economic growth, referenced earlier, suggest that all could be right, depending on the level of taxes, the composition of expenditures, and other factors. In these models, for example, increases in taxes can enhance, have no effect on, or impede growth depending, in particular, on the initial level of taxes, as well as on how the tax revenues are spent. For example, an incremental dollar of tax revenue spent on productive government services has a much more positive effect on growth when taxes are initially low than when they are already high, when the effect may even be negative. This kind of "growth hill" arises from two interacting theoretical forces (as in Barro 1990 and Barro and Sala-i-Martin 1992). Rising taxes exert an increasingly negative effect on growth by depressing the net return to private capital, but expenditures on productive services and infrastructure exert a decreasingly positive effect. Initially, when taxes are low, the additional taxes directed to productive services and infrastructure increase growth, as the positive effects of the latter outweigh the negative effects of the former. Eventually, though, the negative effects of the rising taxes outweigh the positive effects of spending on productive services and infrastructure. 
In subsequent sections, we first present recent data for state fiscal structures, and then present empirical estimates, grounded in a Barro-style growth model, of the linkage between the fiscal structures and growth in real per capita incomes. Next, we use these estimates to evaluate and rank individual state fiscal structures - i.e., taxes, expenditures, and other revenues - on the basis of the extent to which they contribute to or hinder growth in per capita income. These newly developed rankings differ sharply from rankings based only on the level of taxes.

With these rankings in hand, we then proceed to evaluate the effects of two hypothetical policy experiments on real growth in per capita personal income in each state: 1) a tax change with an accompanying change only in spending on productive services and infrastructure; and 2) a change in the relative budget shares for productive services and infrastructure versus social services, with tax rates held constant. We conclude with a summary and assessment of our results, as well as with a discussion of their implications.

We should emphasize at the start that although economic growth is an important criterion in assessing fiscal structures, it is certainly not the only one. We focus on growth here only because it is typically the most prominent concern in comparing state fiscal structures. Other major criteria important in designing and evaluating fiscal structures include equity and fairness, stability and reliability, and ease of compliance and collection.

\section{State and local fiscal structures: 2004}

To provide recent benchmark data for our study, we present in Table 1 total state and local taxes and fees, taxes and fees separately, other state and local revenue, expenditures on economically productive services and infrastructure (i.e., roads, education, public safety, and similar types of expenditures), and expenditures on social services - all expressed as a 
percentage of total state personal income. ${ }^{1}$ There is a certain degree of arbitrariness in the division of government spending into economically productive and consumption-oriented spending. For example, one might argue that health expenditures, particularly those on public health services such as immunization and mosquito abatement should be considered productive government spending. But because of the level of aggregation in the Census Bureau's tabulation of major functional categories of expenditures, it is not possible to parse the data at this fine level of detail. Moreover, the reporting of some of the functional categories has varied over time, adding a further constraint.

Data are for 2004 and include all 50 U.S. states plus the District of Columbia. Median and average values, which do not differ greatly, are noted near the bottom of the table. The median values are 10.13 for Taxes, 4.71 for Fees, and 4.61 for Other Revenues. ${ }^{2}$ The latter primarily represent inter-governmental transfers from the Federal government, which are not under the direct control of states and localities. ${ }^{3}$ Median values for the two broad expenditure categories are 14.64 for Productive Services and Infrastructure and 5.14 for Health, Welfare and Other Related expenditures. We omit the budget surplus or deficit, which for U.S. states is typically quite small on average due to the prevalence of constitutional balanced-budget restrictions.

\footnotetext{
${ }^{1}$ Economically productive services and infrastructure include expenditures on education, transportation, public safety, environment and housing, government administration, interest expenditures, and other expenditures not elsewhere classified. Redistributive and consumption-oriented expenditures include spending on public welfare, hospitals, health, social insurance administration, and veterans’ services.

${ }^{2}$ The Census Bureau defines taxes as "compulsory contributions enacted by government for public purposes." In 2002, sales, property, and income taxes comprised about 92 percent of state and local tax collections. In this paper, fees refer to charges and miscellaneous revenue (other than taxes and federal government transfers). In 2002, four categories of charges accounted for nearly 50 percent of fee revenue: education (18.3 percent), hospitals (16.2 percent), sewerage and solid waste (8.7 percent), and charges related to transportation activities such as highways, airports, sea ports and parking (6.2 percent).

${ }^{3}$ Many Federal transfer programs are matching grants, conditioned on state and/or local spending. Thus, states and localities can influence Federal transfers indirectly through their own budget priorities.
} 
Table 1 also ranks states by total taxes and fees, expressed as a percentage of total state personal income. This ranking is the one most prevalently reported and discussed each year, as the data are reported by the Census Bureau. Even modest changes in the rankings are sometimes front page news in state capitals, especially for states that move from below to above the median, or vice versa. But what information does this ranking actually give us about the extent to which the state fiscal structure enhances or inhibits economic growth?

Note, for example, that Alaska, Wyoming, West Virginia, New York, and New Mexico have the five highest tax rankings, while New Hampshire (the "Live Free or Die” state), Tennessee, South Dakota, Maryland, and Connecticut have the five lowest tax rankings. Are taxes in the five highest states too high for sustained economic prosperity relative to other states, or are taxes too low in the five lowest states? Note, too, that North Dakota has a high tax ranking at 13, but South Dakota has a low tax ranking at 49 . Which is better, the 13 for North Dakota or the 49 for its neighboring state, South Dakota?

We argue here that these questions are at best misleading, at least in the context of the rankings in Table 1. They are misleading because the answers depend theoretically on both the level of taxes and where the tax revenues are spent, as well as empirically on comparisons based on empirical estimates of the actual linkages between fiscal structure and economic growth. As we will find, rankings that account for both these factors are very different from the traditional rankings. The potential importance of accounting for both factors is illustrated in Figure 1, which plots taxes and fees against expenditures on productive services and infrastructure. Each expressed first as percentages of personal income and then converted to deviations from the median values. The importance of both dimensions can be illustrated in several different ways. For example, states with very similar tax rates can have very different levels of spending on 
productive services and infrastructure. Consider, e.g., Florida, Rhode Island, Minnesota, Oregon and Montana -- all of which are near the median level for taxes and fees. Even so, productive spending varies from substantially below to well above the median (e.g., from Florida to Montana).

Alternatively, states with very similar productive spending rates can have very different levels of taxation. Consider, e.g., Massachusetts, Colorado, Texas, Arizona, New Hampshire, Indiana, and West Virginia - all of which are slightly above the median for productive spending. Even so, taxes and fees range from substantially below to well above the median (e.g., from Colorado to West Virginia.

Indeed, the strong clustering of states along a 45 degree diagonal observed in Figure 1, with the exception of a number of outliers, means that a growth-related ranking of states based solely on taxes (from high to low) is roughly an inverse growth-related ranking of states based on their expenditures on productive services and infrastructure. The question is how to assess the negative effects of taxes on growth on the one hand against the positive effects of productive spending on the other. This is the central objective of our paper.

\section{Theory and evidence for comparing fiscal structures}

Our theoretical context for estimating the linkages between fiscal structures and economic growth is drawn from growth models first developed by Barro (1990) and Barro and Sala-i-Martin (1992). In these models, the fiscal linkages to growth depend both on the level of taxes and on where the tax revenues are spent. Taxes exert a nonlinear (i.e., increasingly) negative effect on growth, but expenditures on productive services and infrastructure exert a nonlinear (i.e., decreasingly) positive effect. The interaction of these two forces, when tax 
revenues are spent on productive services and infrastructure, yields a growth hill, where growth initially rises with taxes, reaches a peak, and then declines. ${ }^{4}$

\section{Empirical specification and data}

Our approach here is an extension and elaboration of empirical specifications used by Bania et al (2007). An empirical model of the inflation adjusted percentage growth in per-capita income must account for both revenue sources and expenditures as well as for higherorder, nonlinear effects for taxes and expenditures. Because the government budget constraint is a mathematical identity, it is necessary to omit one component from the empirical specification. In our case we include from Table 1 the variables Taxes, Fees, Other Revenues (Other), and Health, Welfare and Related expenditures $(\mathrm{H} \& \mathrm{~W})$, while omitting the category for expenditures on economically productive services and infrastructure (Prod). Thus, an increase in Taxes, for example, is implicitly spent on Prod, with Fees, Other Revenues, and H\&W held constant. Alternatively, the effect of an increase in Taxes spent on $\mathrm{H} \& \mathrm{~W}$ is measured by the combined effect of equal increases in both Taxes and H\&W, all else the same. ${ }^{5}$ We also include Other Revenues, which primarily consist of inter-governmental transfers from the Federal government, as an auxiliary fiscal variable, even though Other Revenues are not under the direct control of the state. Our measure of economic growth, the dependent variable, is the (log) growth in real personal income per capita in each state.

In addition, we employ three state-level, time-varying controls: the state unemployment rate, the annual budget surplus (or deficit) relative to state personal income, and unemployment

\footnotetext{
${ }^{4}$ Differential economic growth across states may also induce long-term shifts in migration and state populations. Our use of real growth in per capita personal income tends to incorporate these potential effects in our measure of economic growth.

${ }^{5}$ If, instead, Prod were included and H\&W omitted, an increase in Taxes would be implicitly spent on H\&W, all else the same. In this case, the effect of an increase in Taxes spent on Prod would be measured by the combined effect of equal increases in both Taxes and Prod.
} 
insurance expenditures relative to state personal income. ${ }^{6}$ The unemployment rate is included to assist in controlling for short-term cyclical influences, since our intent is to estimate long-run effects. Also, we find, as in Bleaney et al, that two-way fixed effects for both country (in our case, state) and period are important, so all final specifications include two-way fixed effects, which account for fixed differences across states and across years.

Our data for state fiscal variables are taken from the Census of Governments at five year intervals from 1962 through 2002. ${ }^{7}$ Related data for corresponding years are obtained from the Bureau of Labor Statistics for the state unemployment rate, and from the Department of Commerce for real personal income per capita. We exclude Alaska, since the variance in its state fiscal variables is extreme relative to the other 49 states, due in large part to the Alaska pipeline. We also exclude the District of Columbia, as well, since it not a state and idiosyncratic. Thus, we have data for 49 states at five-year intervals from 1962 to 2002, a total of 441 cross-section, time-series observations. We focus on the longer sample period, based on five-year intervals, to better identify long-run effects. Summary statistics for the variables used in our statistical analysis are presented in Table 2. The average value for Growth, our dependent variable, for the five-year data interval is approximately $13 \%$, roughly $2.5 \%$ per annum.

We take the following approach in specifying the dynamics for the growth equation for personal income per capita. First, we assume a priori that the current five-year growth rate is unaffected by contemporaneous fiscal variables, but is a function of the fiscal variables from the previous five-year period. Thus, for example, real personal income growth per capita between

\footnotetext{
${ }^{6}$ Consistent with other studies (e.g., Helms 1985 and Mofidi-Stone 1990), we treat UI expenditures as outside the regular fiscal structure, in part because UI is largely driven federally, with separate accounting. A surplus (or deficit) variable is included only as an auxiliary control, since these are typically small for U.S. states due to constitutional limitations.

${ }^{7}$ The first of the U.S. Census of Governments surveys in our sample is actually for 1963, but our other data are aligned with 1962 to be consistent throughout with the subsequent five-year intervals for the Census of Governments.
} 
1962 and 1967 may be influenced by the values of the fiscal variables in 1962, but is unaffected by the values of these variables in 1967. Mofidi and Stone (1990) successfully employ this recursive approach for five-year data for states. Eberts and Stone (1992) and Mark et al. (2000) employ a similar recursive strategy using longer lags with annual data - the former for major U.S. metropolitan areas, and the latter for jurisdictions in the District of Columbia metropolitan area. Bleaney et al.(2001) find evidence of slightly longer adjustment for OECD countries, about eight years, but we found little gain in additional lags in our estimates. In addition, we employ a lagged dependent variable and instrumental-variable methods. ${ }^{8}$

\section{Estimates for fiscal policy effects}

Table 3 presents regression and Generalized Method of Moments (GMM) instrumental variable estimates for our equation for Growth, the log-change in real personal income per capita (times 100). For all estimates, the fiscal variable omitted from the estimated equation is Prod, the ratio of state and local expenditures on highways, education, and other related items to personal income (times 100). As previously noted, we also include other auxiliary state variables in all columns of Table 3 to control for potentially confounding effects, especially short-term cyclical influences. Again, these are the state unemployment rate, the ratio of the surplus (or deficit) to state personal income, and the ratio of unemployment compensation expenditures to state personal income. The first is entered both contemporaneously and with a one-period lag; the latter two only with a one-period lag consistent with other fiscal variables. The auxiliary variables enter significantly as a group at the five percent level, but have little effect on the

\footnotetext{
${ }^{8}$ Dynamic fixed-effects models can generate biased and/or inefficient parameter estimates arising from the (explicit or implicit) presence of the lagged dependent variable. In our case, the number of periods is well below the number of states included, so the Arellano and Bond (1991) and Arellano and Bover (1995) style generalized method of moment (GMM) estimators are appropriate. These GMM estimators use (first-differenced or orthogonalized) lagged values of the dependent variable and the exogenous (or predetermined) regressors as instruments.
} 
coefficients for the other fiscal variables. Coefficients for the auxiliary controls are omitted in the tables for brevity.

The first column of Table 3 begins with a linear, baseline specification with lagged Taxes, Fees, Other (Revenues), H \&W, and two-way fixed effects for period and state, but without the inclusion of the nonlinear fiscal effects or lagged Growth. The coefficients on Taxes(-1), Fees(-1), and H\&W(-1) are each insignificantly different from zero at the five percent level. ${ }^{9}$ The coefficient for Other Revenues (2.561) is significantly positive. Overall, the fit of the equation (R-squared of 0.649 ) is relatively good for a growth equation with no lagged dependent variable. Taken at face value, these estimates suggest that increases in taxes spent on productive government services have no effect on growth in per capita income.

Returning to our main story, we now estimate a growth equation that is nonlinear in the fiscal variables, but not in the coefficients. First, we estimate the equation incorporating squared and interaction terms for the state-level fiscal variables, i.e., Taxes(-1), Fees(-1), and H\&W(-1). Next, we retain any higher order terms with coefficients in excess of the corresponding standard error. The resulting equation includes only one higher order term, Taxes2(-1), the quadratic term for Taxes(-1). ${ }^{10}$ Of course, higher order terms other than Taxes2(-1) might still be potentially important. If so, the variation in our sample data is insufficient to allow them to be estimated precisely.

We present least-squares results including the nonlinear term for taxes, Taxes2(-1), in the second column of Table 3. These also include fixed effects for both states and periods and the auxiliary control variables. The coefficient on $\operatorname{Tax}(-1)$ is now significantly positive at 5.102, but

\footnotetext{
${ }^{9}$ Estimations are performed in EViews 5.1. The robust standard errors, in this case cross-section SUR, are described in EViews 5: User's Guide (2004, p. 887). The notation (-1) indicates that the variable is lagged by one period - in our case five years.

${ }^{10}$ We apply this strategy based on our preferred GMM specification, column (3) of Table 3.
} 
this linear effect is attenuated by a significantly negative coefficient (-0.216) for Taxes2(-1). Jointly, the linear and quadratic coefficients indicate a growth peak, consistent with a growth hill. The coefficient on $\mathrm{H} \& \mathrm{~W}(-1)$ is now significantly negative (-1.184), if only at the ten percent level. This effect indicates a significant difference in the effect of increasing spending on this category at the expense of productive government services. Of course, the objectives for expenditures for $\mathrm{H} \& \mathrm{~W}$ are broader than simply economic growth, but the negative coefficient in column (2) highlights a potential tradeoff in terms of growth. The coefficient on Fees(-1) is numerically close to zero and remains statistically insignificant, while the coefficient on Other Revenues remains significantly positive and relatively unchanged.

In the third column of Table 3, we add the lagged value of the dependent variable (i.e., Growth(-1)) and present estimates based upon the GMM instrumental-variables estimator. ${ }^{11}$ This estimator uses appropriately lagged values of the dependent variable (in our case to lag 3 , or 15 years) and other exogenous or predetermined regressors as instruments. This procedure accounts for the dynamics of lagged Growth, as well as for potential endogeneity bias. While the coefficient on the lagged dependent variable is significantly negative, as expected, it is relatively small (-0.158). Not surprisingly, then, the Taxes(-1) and Taxes2(-1) coefficients change only modestly and, again, remain significantly positive (6.008) and negative (-0.257), respectively and consistent with a growth hill. ${ }^{12}$ The coefficient for Fees(-1) remains insignificant; the coefficient for $\mathrm{H} \& \mathrm{~W}$ (-0.844) is now significantly negative at the five percent level; and the coefficient for Other Revenues (1.889) is again significantly positive. Near the bottom of the

\footnotetext{
${ }^{11}$ GMM estimates are obtained using E-Views 5.1, with fixed period effects, an orthogonal transformation for crosssection effects, and robust cross-section SUR standard errors.

${ }^{12}$ The peak of the growth hill is at 11.69 for Taxes, calculated by setting the derivative of the estimated equation with respect to taxes equal to zero and solving for Taxes (i.e., 6.008 divided by 2 times 0.2576 ).
} 
table, the J-statistic (25.55)) for the validity of the over-identifying restrictions fails to reject the restrictions at the five percent level.

\section{Rankings of state fiscal structures}

We are now in a position to compare the extent to which individual state fiscal structures contribute to or hinder economic growth, as measured by real growth in personal income per capita. Our primary ranking is a comprehensive one based on the fiscal variables directly under state and local control, i.e., Taxes, Fees, and H\&W (and, implicitly, Prod). A second incorporates Other Revenues, which reveals the extent to which relative economic growth for states is affected by inter-governmental transfers from the Federal government. Rankings of state fiscal structures

The first set of comparisons in Table 4 presents our primary rankings for individual state fiscal structures. The rankings are based on the estimated effect of each state's fiscal structure on real growth in personal income per capita. This effect is calculated by weighting Taxes, Taxes2, and H\&W for 2004 in Table 1 by the corresponding coefficients in the estimated growth equation, column 3 in Table 3. These comparisons reveal substantial variations in growth relative to the median state, which arise from variations in the level of taxes and the relative composition of expenditures on H\&W versus Prod. ${ }^{13}$ More specifically, growth varies because, for any given composition of expenditures, tax revenues available from taxes could be either too high or too low in terms of growth; and also because, for any given level of taxes, the composition of government expenditures may be more or less conducive to growth, depending on the ratio of expenditures on productive services and infrastructure to health and welfare expenditures.

\footnotetext{
${ }^{13}$ Taxes for the median state (10.13) fall just short of the peak of the growth hill for taxes (11.69).
} 
Consider the first state at the top of the list in Table 4, Alabama. Alabama's fiscal structure lowers its growth rate by approximately 4 percentage points below that of the median state for a five year period, or nearly one percentage point in growth per annum. This differential emerges both because taxes are relatively low, reducing revenues available for productive services and infrastructure, and because the ratio of the latter to health and welfare expenditures is also relatively low. ${ }^{14}$ At the other extreme, New Jersey’s fiscal structure raises its growth rate by 2.3 percent above that of the median state. In this case, while taxes are modestly below the median, the ratio of health and welfare expenditures to expenditures on productive services and infrastructure is markedly lower - yielding a more positive effect on growth than for the median state. Note that there is little difference in the impact of the fiscal structures of the median and average state, since the differential from the median for the latter is only 0.03 in Table 4.

To what extent do these rankings differ from those in Table 1, which are based solely on the level of taxes? The Table 1 rankings go from high- to low-tax states. Our rankings in Table 4 go from fiscal structures with low-growth to high-growth impacts. The correlation between the two sets of rankings should be perfect (1.00) if they contained exactly the same information regarding the growth impact of state fiscal structures. However, the estimated correlation coefficient (0.184) is not significantly different from zero ( $p$ value of 0.206 ). Surprisingly, the traditional rankings in Table 1, based solely on the linear value of Taxes appear to provide no information on the overall impact of individual state fiscal structures on economic growth. Both the non-monotonic effects of taxes and where taxes are spent are important to economic growth

\footnotetext{
${ }^{14}$ Note that unlike Taxes, Fees in Alabama are relatively high. However, we find little net effect for fees on economic growth, at least as currently used in most states. Theoretically and empirically, fees often play a role in both reducing access to public goods subject to congestion and in expanding the availability of the public goods.
} 
- so much so, that rankings based solely on linear measures of taxes appear to provide no information about long-term growth.

Rankings that incorporate Federal transfers

To what extent do Federal transfers to state and local governments (which account for most of Other Revenues) alter the effects of individual state fiscal structures on economic growth? To examine this question we add the estimated impact of Other Revenues on growth to the first set of calculations. That is, we add to the first calculation the effect of Other Revenues on growth by weighting Other Revenues for 2004 from Table 1 by the corresponding coefficient for Other Revenues from column 3 of Table 3. Again, the comparison is for an individual state relative to the median state. These rankings and calculations are presented in the second set of comparisons in Table 4.

Clearly, Federal transfers play a major role. At one extreme, for example, the rankings for Mississippi, New Mexico, New York, and Wyoming now shift from 3 to 43, 8 to 45, 4 to 32, and 7 to 49, respectively. For these states, the poor ranking for effects of their fiscal structure on growth is substantially reversed by the role of Federal transfers. At the other extreme, the rankings for Colorado, Florida, Nevada, and Virginia now shift from 26 to 3, 33 to 8, 48 to 5, and 35 to 1, respectively. For these states, the strong ranking for effects of their fiscal structure on growth is also substantially reversed by including Federal transfers in the ranking.

If the differential effects of individual state fiscal structures on economic growth were precisely offset by Federal transfers, then one would expect: 1) no significant correlation between the two rankings; and 2) little variation in the growth effects in the second set of comparisons. Indeed, the actual correlation (-0.204) is insignificant (p value of 0.160), suggesting that the growth variations arising from state fiscal structures do tend to be offset by 
Federal transfers. However, substantial variations remain in the growth differentials in the second set of comparisons, which means that Federal transfers, perhaps unsurprisingly, introduce other, independent differentials in relative growth rates.

One might expect this pattern of results for at least two reasons. One is that an objective of Federal transfers is to "even out” the burden of dealing with poverty and other related economic and social needs of populations in individual states. This Federal role helps to ease what might otherwise be a vicious circle of high poverty and welfare needs, low investments in productive services and infrastructure, and low growth. A second reason is that Federal expenditures in many areas are driven by national priorities: important resources are concentrated in certain states, water and other transportation systems are not uniformly distributed across individual states, and defense spending is often linked to particular locales or regions.

\section{Rankings for Two Policy Experiments}

So far, our rankings assess the overall impact of an individual state's fiscal structure on economic growth, with and without incorporating the role of Federal transfers. In this section, we address two policy-oriented questions involving hypothetical changes in taxes and the composition of expenditures: 1) What is the effect on economic growth of an increment in taxes dedicated solely to productive services and infrastructure? And 2) what is the effect on economic growth of a shift in the relative budget shares for productive services and expenditures and for health, welfare and related programs, with taxes held constant? Both questions provide information relevant to potential changes in state fiscal policies, at least with regard to the effects on economic growth. 
Policy experiment 1: a tax change devoted to productive services and infrastructure

This question can be answered by calculating the mathematical derivative of our estimated growth equation (column 3 in Table 3) with respect to Taxes, with other factors held constant. For each state this derivative equals 6.008 plus 2 times -0.257 multiplied by the value of Taxes for 2004 from Table 1. Intuitively, the observed tax rate in each state is increased by one percentage point, with all of the incremental revenues devoted to productive services and infrastructure. The difference in growth rates is calculated as the growth rate implied by the observed tax rate less the growth rate implied by the new higher tax rates. Why is this question interesting? Consider, again, the state of Alabama, which ranks number one in the first ranking in Table 4, i.e., it appears to have the fiscal structure least conducive to economic growth - both because taxes are low and because the ratio of expenditures on productive services and infrastructure to health and welfare expenditures is also relatively low. What this means, though, is that an increment in taxes devoted exclusively to productive services and infrastructure would yield a relatively high payoff in terms of economic growth.

At the other extreme, New Jersey, for example, which ranks 49 in the first ranking in Table 4, appears to have the fiscal structure most conducive to economic growth - because taxes are near those of the median state (which are near the peak of the growth hill for taxes) and the composition of expenditures is heavily tilted toward productive services and investments, with a relatively low budget share for health and welfare expenditures. What this means, in contrast to the case for Alabama, is that an increment in taxes, even if devoted exclusively to productive services and infrastructure, might even reduce economic growth.

Comparisons for an incremental change in taxes devoted exclusively to productive services and infrastructure are presented in Table 5. As expected, states like Alabama, with low 
taxes and a low share of expenditures on productive services and infrastructure, rank relatively well (at 49, in the case of Alabama). A one-percentage point increase in taxes, devoted solely to productive services and infrastructure, all else the same, yields 1.69 percent addition growth over a five-year period, or roughly $0.34 \%$ per year. Note, too, that absolute expenditures on $\mathrm{H} \& \mathrm{~W}$ would also increase over time if the budget share for $\mathrm{H} \& \mathrm{~W}$ remained constant due to the higher rate of growth. By contrast, states like New Jersey, with taxes near the median (and peak of the growth hill), do not rank well (at 10 for New Jersey) for an increment in taxes spent productively.

Of course, a state could instead start out with high taxes, well above those for the median state. If the share of expenditures on productive investments is also relatively low, as for Wyoming, for example, then the state's fiscal structure will not rank well in the first set of rankings for the overall fiscal structure (where Wyoming is 7) or in the hypothetical increase in taxes, even if the incremental revenues are devoted to productive investments.

Policy experiment \#2: a shift in budget shares for Prod versus H\&W

Our second policy experiment holds tax rates and other factors constant, and instead increases the budget share for productive services and infrastructure by decreasing the relative budget share for health, welfare and related programs. Because Prod is omitted from the estimation, the coefficient on $\mathrm{H} \& \mathrm{~W}$ measures the effect of a change in $\mathrm{H} \& \mathrm{~W}$ that is offset by an equal change (of opposite sign) in Prod. Therefore, this effect is taken directly from the coefficient on H\&W in the third (GMM) set of estimates in Table 3, with only a change in sign from negative to positive (from -0.844 to +0.844 ). Since this effect is linear and other factors are held constant, it is the same for every state, and equal to (minus) the coefficient on $\mathrm{H} \& \mathrm{~W}$ 
(-0.844). Therefore decreasing H\&W by one percentage point and shifting these expenditures to Prod is estimated to increase the growth in real personal income per capita by just under one percentage point per five-year interval (or by about 0.17 percentage points per annum), all else the same. Of course, a shift in budget share in the opposite direction, i.e., from Prod to H\&W, is measured by simply changing the direction of the coefficient, i.e., from +0.844 to -0.844 . Consequently, a one percentage point increase in $\mathrm{H} \& \mathrm{~W}$ funded by an equivalent decrease in Prod is estimated to reduce the growth in real personal income per capita by just under one percentage point per five-year interval (or by about 0.17 percentage points per annum), all else the same.

While the effect of a budget shift from H\&W to Prod may appear small, the resulting higher growth in per-capita income may result in higher absolute H\&W expenditures in the future. If after the initial reduction in the H\&W share the relative budget shares of Prod and H\&W remain constant, then the higher growth in per-capita income that results from this budget shift will eventually restore the $\mathrm{H} \& \mathrm{~W}$ expenditures to its original level. In fact, all else the same, this restoration of $\mathrm{H} \& \mathrm{~W}$ expenditures will occur after only 6 years of the higher steady-state growth rate. After a full 25-year generation, real personal income per capita would be roughly five percentage points higher as a result of the one percentage point shift in budget shares, and absolute expenditures on $\mathrm{H} \& \mathrm{~W}$ would be higher in percentage terms by roughly four times the reduced budget share for $\mathrm{H} \& \mathrm{~W}$ from the experiment.

Thus, this second policy experiment highlights, in particular, very difficult short- and long-term tradeoffs inherent in trying to improve funding for social services. A shift in budget shares toward productive services and infrastructure will temporarily decrease the absolute level of expenditures for $\mathrm{H} \& \mathrm{~W}$, but the higher growth will, over time, eventually raise the absolute 
level of expenditures if the budget share remains constant. Conversely, a shift in budget shares toward H\&W temporarily increases the absolute level of expenditures for $\mathrm{H} \& \mathrm{~W}$, but the lower growth will, over time, eventually lower the absolute level of expenditures if the budget share remains constant.

A further complication in evaluating either of the two policy experiments is the assumption that other factors, including Federal transfers, are constant. In practice, some tax and budgetary shifts may or may not induce, either directly or indirectly, corresponding shifts in Federal transfers. For example, a state decision to spend more on highways or public safety may or may not induce corresponding Federal transfers to subsidize these investments. Or, a decision to spend more on state or local social services may or may not induce adjustments in Federal support for these programs in the state. These detailed considerations are important in practice, but beyond the scope of the current paper.

\section{Concluding remarks}

This paper offers unique rankings of the extent to which fiscal structures of U.S. states contribute to economic growth. Fiscal structures are designed, of course, with many complex and often competing goals in mind. We focus here only on economic growth, as measured by growth in personal income per capita, since the traditional and most publicized tax rankings tend to focus on issues of state competitiveness and economic growth. The rankings are novel in two key respects: they are well grounded in established growth theory, where the effect of taxes depends both on the level of taxes and on the composition of expenditures; and they are derived from actual estimates of the link between fiscal structures and economic growth. Estimates for the latter yield a growth hill, in which the incremental effect of taxes spent on productive services and infrastructure initially rises, reaches a peak, and then declines. Rankings derived 
from these estimates differ sharply from typical rankings based on levels of taxation alone. Indeed, our results suggest that the traditional rankings provide no comparative information whatsoever on the impact of individual state fiscal structures on economic growth, since the correlation between the traditional rankings and our rankings grounded in both theory and evidence is not statistically significant.

In a second set of comparisons in which we incorporate the role of Federal transfers to state and local governments, we find that these transfers significantly attenuate the effects of individual state fiscal structures on economic growth. At the same time, Federal transfers introduce substantial additional variations in growth. We are not surprised at the former, since one objective of many Federal transfer programs is to mitigate the potential vicious circle of high taxes, low investments in productive services and infrastructure (and high expenditures on health and welfare), and low rates of economic growth.

Our final set of comparisons considers the growth effects of two alternative policy experiments: 1) An increment in taxes dedicated solely to productive services and infrastructure; and 2) a shift in the relative budget shares for productive services and expenditures versus social services, with taxes held constant. In the first experiment, states with fiscal structures not relatively conducive to growth, i.e., those states with relatively low investments in productive services and infrastructure and with low tax rates, will experience relatively large increases in economic growth. Other states with fiscal structures not relatively conducive to growth, i.e., states with tax rates well above the median, will likely reduce growth with further increases in taxes, even if spent on productive investments.

In the second experiment, our results tend to highlight the very difficult short- and longterm tradeoffs in building strong social services. For example, an increase in the budget share 
for social services funded by a decrease in the budget share for productive services and infrastructure (or, alternatively by an increase in taxes) will typically temporarily increase the absolute level of expenditures on social services, but due to the accumulated effects of lower growth rate, expenditures on social services will eventually decline (all else the same).

So, will a tax cut improve incentives and investment, stimulating increased growth? Or, will a tax increase stimulate growth if the incremental revenues are spent on productive services and infrastructure? Our evidence here suggests that the answer is: "It depends." Traditional rankings based only on tax rates do not provide an answer. Our rankings, numerical comparisons, and hypothetical policy experiments provide some of the information required to understand why "it depends" and some of the key factors on which the answer does in fact depend.

Finally, several possible extensions of this paper merit further exploration. First, many state policy makers may be interested in employment growth as well as the growth of per-capita income. To what extent is this framework helpful in understanding the determinants of employment growth? Second, our framework does not distinguish between different types of taxes (e.g. sales, income, and property). How does the composition of taxes affect the results reported here? Third, to what extent can one distinguish among more detailed categories of expenditures in identifying their effects on growth? For example, are expenditures on education and highways equally productive in terms of long term growth? Conversely, do all social services involve the same tradeoff against growth, or do some, e.g., public health programs, involve less of a tradeoff, if any? We hope that findings in this study will serve to motivate investigations of these and other related questions. 


\section{References}

Arellano, Manuel and Stephen Bond. "Some Tests of Specification for Panel Data: Monte Carlo Evidence and an Application to Employment Equations," Review of Economic Studies 58 No. 2 (April, 1991): 277-97.

Arellano, Manuel and Olympia Bover. “Another Look at the Instrumental Variables Estimation of Error-Components Models,” Journal of Econometrics 68 No. 1 (July, 1995): 29-51.

Bania, Neil, Gray, Jo Anna, and Joe Stone, "Growth, Taxes, and Government Expenditures: Growth Hills for U.S. States,” National Tax Journal (forthcoming, 2007).

Barro, Robert. “Government Spending in a Simple Model of Endogenous Growth,” Journal of Political Economy 98 No. 5 (October, 1990): 103-117.

Barro, Robert and Xavier Sala-i-Martin. "Public Finance in Models of Economic Growth,” Review of Economic Studies 59 No. 4 (October, 1992): 645-661.

Bleaney, M., Gemmell, N. and R. Kneller. (2001) “Testing the Endogenous Growth Model: Public Expenditure, Taxation, and Growth over the Long Run,” Canadian Journal of Economics 34 No. 1 (February, 2001): 36-57.

Cohen, Jeffrey and Catherine Paul. "Public Infrastructure Investment, Interstate Spatial Spillovers, and Manufacturing Costs,” Review of Economics and Statistics 86 No.2 (October, 2004): 551-60.

Eberts, Randall and Joe Stone. Wage and Employment Adjustment in Local Labor Markets, Kalamazoo, MI: W. E. Upjohn Institute for Employment Research, 1992.

EViews: User's Guide. Irvine, CA: Quantitative Micro Software, LLC, 2004.

Helms, L. Jay. "The Effect of State Local Taxes on Economic Growth: A Time Series-Cross Section Approach,” Review of Economics and Statistics 67 No. 4 (November, 1985): 574-582.

Holcombe, Randall and Donald Lacombe. "The Effect of State Income Taxation on Per Capita Income Growth,” Public Finance Review 32 No. 3 (May, 2004): 2004.

Kneller, Richard, Bleaney, Michael and Norman Gemmell. "Fiscal Policy and Growth: Evidence from OECD Countries,” Journal of Public Economics 74 No. 2 (November, 1999): 171-90.

Mark, Stephen, McGuire, Therese and Leslie Papke. “The Influence of Taxes on Employment and Population Growth: Evidence from the Washington, D.C. Metropolitan Area,” National Tax Journal 53 No. 1 (2000): 105-124.

Mofidi, Ala and Joe Stone. “Do State and Local Taxes Affect Economic Growth?” Review of Economics and Statistics 72 No. 4 (November, 1990): 1990. 
Pereira, Alfred. “Is All Public Capital Created Equal?” Review of Economics and Statistics 82 No. 3 (August, 2000): 513-8.

Poot, Jacques."A Synthesis of Empirical Research on the Impact of Government on Long-Run Growth,” Growth and Change 31 No. 4 (Fall, 2000): 516-46. 
Figure 1. State and Local Taxes and Fees vs. Productive Expenditures, 2004

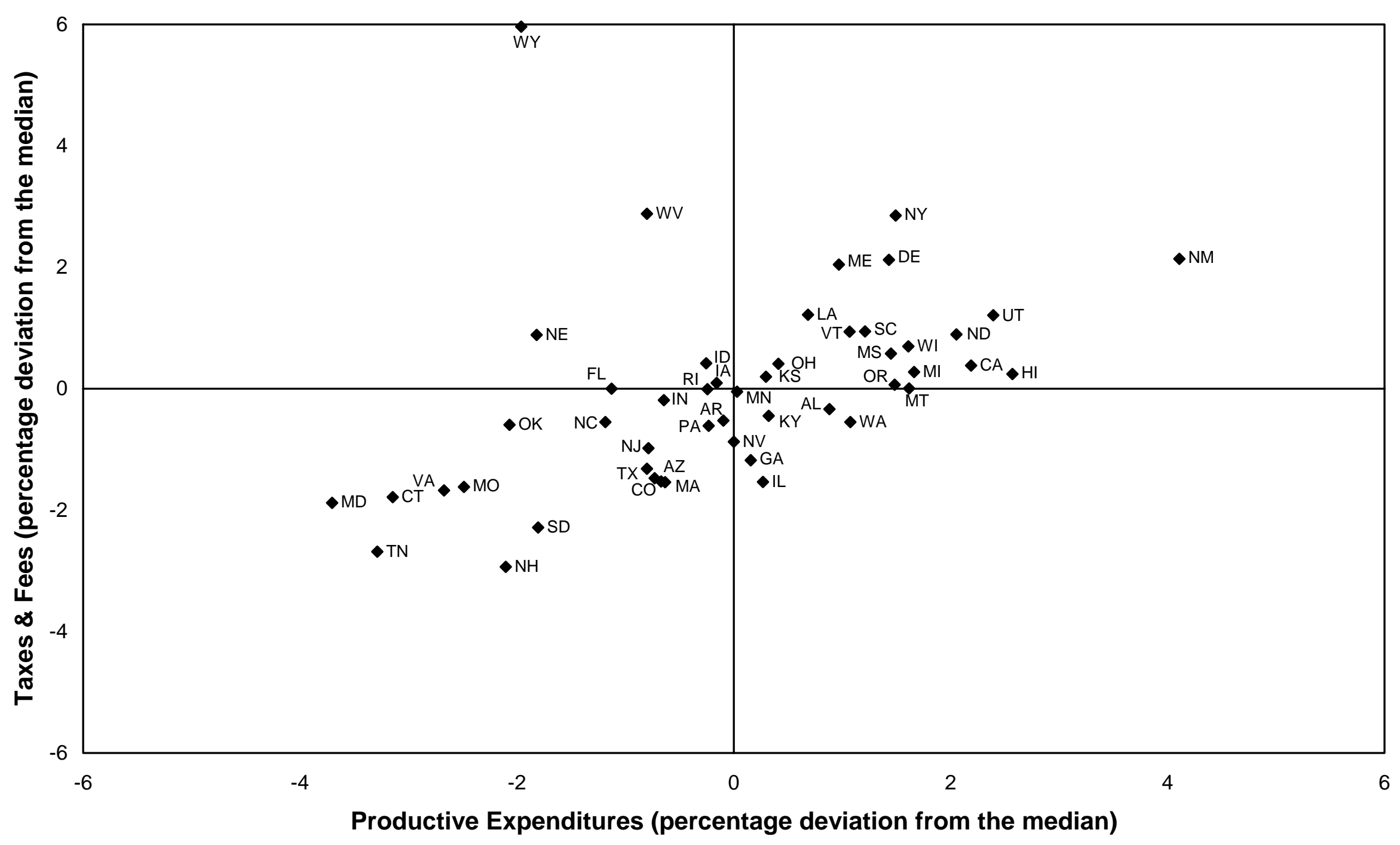




\begin{tabular}{|c|c|c|c|c|c|c|c|}
\hline & & & \\
\hline & & & & & & & \\
\hline & & \multicolumn{4}{|c|}{-------------------- Revenues -------------------- } & \multicolumn{2}{|c|}{------------- Expenditures ------------. } \\
\hline & Ranking & Taxes & & & & Productive & Health, \\
\hline & by Taxes & plus & & & Other & Services \& & Welfare \& \\
\hline State & plus Fees & Fees & Taxes & Fees & Revenue & Infrastructure & Other Related \\
\hline Alaska & 1 & 27.32 & 10.62 & 16.69 & 10.82 & 30.62 & 7.22 \\
\hline Wyoming & 2 & 21.23 & 12.95 & 8.28 & 11.43 & 12.68 & 6.96 \\
\hline West Virginia & 3 & 18.15 & 10.63 & 7.53 & 7.36 & 13.84 & 6.06 \\
\hline New York & 4 & 18.12 & 13.75 & 4.37 & 6.19 & 16.13 & 7.38 \\
\hline New Mexico & 5 & 17.41 & 10.93 & 6.48 & 7.63 & 18.75 & 6.85 \\
\hline D.C. & 6 & 17.40 & 13.98 & 3.42 & 9.55 & 11.53 & 8.94 \\
\hline Delaware & 7 & 17.39 & 10.10 & 7.29 & 3.68 & 16.07 & 4.62 \\
\hline Maine & 8 & 17.31 & 12.61 & 4.70 & 6.77 & 15.61 & 7.31 \\
\hline Louisiana & 9 & 16.49 & 10.62 & 5.87 & 6.20 & 15.32 & 6.30 \\
\hline Utah & 10 & 16.48 & 10.28 & 6.20 & 5.00 & 17.03 & 4.68 \\
\hline South Carolina & 11 & 16.21 & 9.79 & 6.42 & 5.44 & 15.85 & 7.34 \\
\hline Vermont & 12 & 16.21 & 11.58 & 4.63 & 6.93 & 15.71 & 5.71 \\
\hline North Dakota & 13 & 16.17 & 10.13 & 6.04 & 7.00 & 16.69 & 4.44 \\
\hline Nebraska & 14 & 16.16 & 11.16 & 5.00 & 4.49 & 12.82 & 4.73 \\
\hline Wisconsin & 15 & 15.97 & 11.55 & 4.42 & 4.10 & 16.25 & 5.16 \\
\hline Mississippi & 16 & 15.85 & 9.97 & 5.88 & 7.93 & 16.09 & 8.73 \\
\hline Idaho & 17 & 15.69 & 10.15 & 5.54 & 5.00 & 14.38 & 5.14 \\
\hline Ohio & 18 & 15.68 & 10.97 & 4.71 & 4.57 & 15.65 & 5.82 \\
\hline California & 19 & 15.65 & 10.61 & 5.04 & 4.31 & 16.83 & 5.11 \\
\hline Michigan & 20 & 15.55 & 10.33 & 5.22 & 4.66 & 16.30 & 5.26 \\
\hline Hawaii & 21 & 15.51 & 11.69 & 3.82 & 4.45 & 17.21 & 4.96 \\
\hline Kansas & 22 & 15.47 & 10.88 & 4.59 & 3.69 & 14.93 & 4.25 \\
\hline Iowa & 23 & 15.37 & 9.83 & 5.53 & 4.69 & 14.48 & 5.68 \\
\hline Oregon & 24 & 15.34 & 9.54 & 5.79 & 4.50 & 16.12 & 4.70 \\
\hline Montana & 25 & 15.27 & 9.48 & 5.79 & 7.34 & 16.25 & 4.41 \\
\hline Florida & 26 & 15.27 & 9.83 & 5.44 & 3.51 & 13.51 & 4.55 \\
\hline Rhode Island & 27 & 15.26 & 11.38 & 3.88 & 5.75 & 14.39 & 6.12 \\
\hline Minnesota & 28 & 15.22 & 10.53 & 4.69 & 3.88 & 14.67 & 5.96 \\
\hline Indiana & 29 & 15.08 & 9.93 & 5.15 & 3.90 & 13.99 & 4.82 \\
\hline Alabama & 30 & 14.93 & 8.41 & 6.53 & 5.44 & 15.52 & 7.33 \\
\hline Kentucky & 31 & 14.82 & 10.15 & 4.68 & 5.53 & 14.96 & 6.04 \\
\hline Arkansas & 32 & 14.75 & 9.82 & 4.92 & 6.03 & 14.54 & 5.76 \\
\hline Washington & 33 & 14.72 & 9.85 & 4.87 & 3.56 & 15.71 & 5.17 \\
\hline North Carolina & 34 & 14.72 & 9.99 & 4.73 & 4.76 & 13.45 & 5.80 \\
\hline Oklahoma & 35 & 14.68 & 9.62 & 5.06 & 4.91 & 12.57 & 4.93 \\
\hline Pennsylvania & 36 & 14.66 & 10.35 & 4.31 & 4.39 & 14.41 & 5.55 \\
\hline Nevada & 37 & 14.40 & 10.11 & 4.28 & 2.44 & 14.64 & 3.09 \\
\hline New Jersey & 38 & 14.29 & 10.94 & 3.35 & 2.75 & 13.85 & 3.03 \\
\hline Georgia & 39 & 14.09 & 9.66 & 4.43 & 3.73 & 14.80 & 5.19 \\
\hline Texas & 40 & 13.95 & 9.37 & 4.58 & 4.01 & 13.84 & 4.13 \\
\hline Colorado & 41 & 13.79 & 8.77 & 5.02 & 3.13 & 13.91 & 3.38 \\
\hline Arizona & 42 & 13.74 & 10.02 & 3.72 & 4.61 & 13.97 & 4.24 \\
\hline Illinois & 43 & 13.73 & 10.24 & 3.49 & 3.55 & 14.91 & 3.84 \\
\hline Massachusetts & 44 & 13.73 & 10.00 & 3.73 & 3.72 & 14.01 & 4.53 \\
\hline Missouri & 45 & 13.65 & 9.26 & 4.39 & 4.57 & 12.15 & 4.98 \\
\hline Virginia & 46 & 13.60 & 9.24 & 4.35 & 2.61 & 11.97 & 3.59 \\
\hline Connecticut & 47 & 13.49 & 10.86 & 2.63 & 2.84 & 11.49 & 3.74 \\
\hline Maryland & 48 & 13.39 & 10.13 & 3.26 & 3.29 & 10.93 & 3.33 \\
\hline South Dakota & 49 & 12.98 & 8.66 & 4.33 & 5.84 & 12.83 & 3.84 \\
\hline Tennessee & 50 & 12.59 & 8.50 & 4.09 & 5.41 & 11.35 & 6.56 \\
\hline New Hampshire & 51 & 12.34 & 8.56 & 3.78 & 3.31 & 12.54 & 3.56 \\
\hline (median) & & 15.27 & 10.13 & 4.71 & 4.61 & 14.64 & 5.14 \\
\hline (average) & & 15.51 & 10.36 & 5.16 & 5.12 & 14.86 & 5.31 \\
\hline Source: U.S. Ce & sus Bure & 04. & & & & & \\
\hline
\end{tabular}




\begin{tabular}{|c|c|c|c|c|c|}
\hline \multicolumn{6}{|c|}{ Table 2 Means of Variables used in Statistical Analysis } \\
\hline \multicolumn{2}{|c|}{$(1962-2002)$} & \multirow[b]{2}{*}{ Mean } & \multirow[b]{2}{*}{ Std. Dev. } & \multirow[b]{2}{*}{ Minimum } & \multirow[b]{2}{*}{ Maximum } \\
\hline Variable & Definition & & & & \\
\hline \multirow[t]{2}{*}{ Growth } & log change in state real personal & 12.69 & 5.55 & -8.55 & 29.08 \\
\hline & income per capita (x100) & & & & \\
\hline \multirow[t]{2}{*}{ Taxes } & ratio of state $\&$ local taxes & 10.17 & 1.38 & 7.47 & 17.97 \\
\hline & to personal income (x100) & & & & \\
\hline \multirow[t]{2}{*}{ Fees } & ratio of state and local fees & 3.93 & 1.47 & 1.37 & 12.83 \\
\hline & to personal income $(\mathrm{x} 100)$ & & & & \\
\hline \multirow[t]{2}{*}{ Other Revenue } & ratio of other state and local & 3.59 & 1.14 & 1.24 & 7.59 \\
\hline & revenues to personal income (x100) & & & & \\
\hline \multirow[t]{3}{*}{ Prod } & ratio of state and local expenditures & 13.87 & 2.28 & 9.1 & 26.35 \\
\hline & on productive services and infra- & & & & \\
\hline & structure to personal income (x100) & & & & \\
\hline \multirow[t]{3}{*}{$\mathrm{H} \& \mathrm{~W}$} & ratio of state and local expenditures & 3.45 & 1.11 & 1.36 & 6.85 \\
\hline & on health, welfare and related pro- & & & & \\
\hline & grams to personal income (x100) & & & & \\
\hline \multicolumn{6}{|c|}{ Auxiliary control variables } \\
\hline \multirow[t]{2}{*}{ Surplus } & ratio of total state and local surplus & 0.36 & 0.99 & -2.42 & 8.62 \\
\hline & (deficit) to personal income (x100) & & & & \\
\hline \multirow[t]{3}{*}{ UI } & ratio of state and local expenditures & 0.49 & 0.3 & 0.07 & 1.7 \\
\hline & on unemployment insurance relative & & & & \\
\hline & to personal income (x100) & & & & \\
\hline UR & state unemployment rate (x100) & 6.07 & 2.28 & 2 & 15.45 \\
\hline Note: See text $\mathrm{f}$ & or sources of data. & & & & \\
\hline
\end{tabular}




\section{Table 3 Estimated Fiscal Effects on Economic Growth}

\begin{tabular}{|c|c|c|c|}
\hline Variable & $\begin{array}{c}\text { Linear } \\
\text { Model } \\
(O L S-F E)\end{array}$ & $\begin{array}{c}\text { Nonlinear } \\
\text { Model } \\
(O L S-F E)\end{array}$ & $\begin{array}{c}\text { Nonlinear } \\
\text { Model } \\
\text { (GMM-FE) }\end{array}$ \\
\hline constant & $\begin{array}{c}14.232 * * \\
(6.242)\end{array}$ & $\begin{array}{l}-13.414 \\
(11.037)\end{array}$ & -- \\
\hline Taxes(-1) & $\begin{array}{c}0.175 \\
(0.427)\end{array}$ & $\begin{array}{c}5.102 * * \\
(1.557)\end{array}$ & $\begin{array}{c}6.008 * * \\
(1.081)\end{array}$ \\
\hline Taxes2(-1) & & $\begin{array}{c}-0.216^{* *} \\
(0.065)\end{array}$ & $\begin{array}{c}-0.257 * * \\
(0.045)\end{array}$ \\
\hline Fees(-1) & $\begin{array}{c}0.180 \\
(0.696)\end{array}$ & $\begin{array}{c}0.368 \\
(0.662)\end{array}$ & $\begin{array}{c}0.012 \\
(0.290)\end{array}$ \\
\hline Other(-1) & $\begin{array}{c}2.561 * * \\
(0.651)\end{array}$ & $\begin{array}{c}2.380 * * \\
(0.605)\end{array}$ & $\begin{array}{c}1.889 * * \\
(0.342)\end{array}$ \\
\hline$H \& W(-1)$ & $\begin{array}{l}-1.184 \\
(0.665)\end{array}$ & $\begin{array}{c}-1.216^{*} \\
(0.632)\end{array}$ & $\begin{array}{c}-0.844^{* *} \\
(0.345)\end{array}$ \\
\hline Growth(-1) & & & $\begin{array}{c}-0.158 * * \\
(0.042)\end{array}$ \\
\hline $\begin{array}{l}\text { State fixed effects } \\
\text { Period fixed effects }\end{array}$ & $\begin{array}{l}\text { yes } \\
\text { yes }\end{array}$ & $\begin{array}{l}\text { yes } \\
\text { yes }\end{array}$ & $\begin{array}{l}\text { yes } \\
\text { yes }\end{array}$ \\
\hline $\begin{array}{l}\text { R squared } \\
\text { J-statistic }\end{array}$ & 0.649 & 0.663 & $\begin{array}{c}0.658 \\
25.547\end{array}$ \\
\hline \# obs & 392 & 392 & 343 \\
\hline \multicolumn{4}{|c|}{ ** significant at the five percent level (* at ten percent level). } \\
\hline \multicolumn{4}{|c|}{$\begin{array}{l}\text { Notes: Dependent variable is log change in personal income per capita. Data } \\
\text { are for } 49 \text { of the } 50 \text { states in the U.S. (Alaska is excluded) from } 1962 \text { to } 1997 \\
\text { in five-year intervals. See text for sources and further details. Robust (panel- } \\
\text { corrected, cross-section SUR) standard errors are in parentheses. The J-statistic } \\
\text { is a test of the validity of the over-identifying restrictions in the GMM } \\
\text { instrumental variables estimates in column (3). }\end{array}$} \\
\hline
\end{tabular}


Table 4 Effects of State Fiscal Structures on Real Growth in Personal Income Per Capita

\begin{tabular}{|c|c|c|c|c|c|}
\hline \multirow[b]{2}{*}{ State } & \multicolumn{2}{|c|}{ State Fiscal Structure } & \multirow[b]{2}{*}{ State } & \multicolumn{2}{|c|}{$\begin{array}{l}\text { State Fiscal Structure plus } \\
\text { Federal Transfers }\end{array}$} \\
\hline & Ranking & $\begin{array}{c}\text { Growth relative to } \\
\text { median }\end{array}$ & & Ranking & $\begin{array}{c}\text { Growth relative to } \\
\text { median }\end{array}$ \\
\hline Alabama & 1 & -4.00 & Virginia & 1 & -3.39 \\
\hline Tennessee & 2 & -3.19 & New Hampshire & 2 & -3.03 \\
\hline Mississippi & 3 & -3.17 & Colorado & 3 & -2.86 \\
\hline New York & 4 & -2.36 & Alabama & 4 & -2.43 \\
\hline South Carolina & 5 & -2.16 & Nevada & 5 & -2.39 \\
\hline Maine & 6 & -1.42 & Washington & 6 & -2.26 \\
\hline Wyoming & 7 & -1.32 & Georgia & 7 & -2.14 \\
\hline New Mexico & 8 & -0.97 & Florida & 8 & -1.85 \\
\hline Arkansas & 9 & -0.79 & Minnesota & 9 & -1.79 \\
\hline Missouri & 10 & -0.75 & Connecticut & 10 & -1.71 \\
\hline Kentucky & 11 & -0.74 & Tennessee & 11 & -1.67 \\
\hline Iowa & 12 & -0.72 & Delaware & 12 & -1.34 \\
\hline North Carolina & 13 & -0.67 & Massachusetts & 13 & -1.27 \\
\hline Louisiana & 14 & -0.64 & New Jersey & 14 & -1.26 \\
\hline South Dakota & 15 & -0.64 & Indiana & 15 & -1.24 \\
\hline New Hampshire & 16 & -0.57 & Texas & 16 & -1.03 \\
\hline Georgia & 17 & -0.48 & Maryland & 17 & -0.96 \\
\hline West Virginia & 18 & -0.44 & Missouri & 18 & -0.83 \\
\hline Minnesota & 19 & -0.41 & Illinois & 19 & -0.83 \\
\hline Oklahoma & 20 & -0.30 & Pennsylvania & 20 & -0.61 \\
\hline Washington & 21 & -0.27 & South Carolina & 21 & -0.59 \\
\hline Rhode Island & 22 & -0.23 & Iowa & 22 & -0.56 \\
\hline Pennsylvania & 23 & -0.18 & Kansas & 23 & -0.52 \\
\hline Oregon & 24 & -0.18 & North Carolina & 24 & -0.40 \\
\hline Ohio & 25 & -0.08 & Oregon & 25 & -0.39 \\
\hline Colorado & 26 & -0.07 & Wisconsin & 26 & -0.36 \\
\hline Montana & 27 & -0.01 & California & 27 & -0.23 \\
\hline Idaho & 28 & 0.01 & Ohio & 28 & -0.15 \\
\hline Michigan & 29 & 0.04 & Michigan & 29 & 0.14 \\
\hline Indiana & 30 & 0.10 & Oklahoma & 30 & 0.28 \\
\hline Texas & 31 & 0.10 & Hawaii & 31 & 0.48 \\
\hline Vermont & 32 & 0.14 & New York & 32 & 0.64 \\
\hline Florida & 33 & 0.24 & Nebraska & 33 & 0.67 \\
\hline California & 34 & 0.35 & Arizona & 34 & 0.67 \\
\hline Virginia & 35 & 0.39 & Idaho & 35 & 0.75 \\
\hline Massachusetts & 36 & 0.41 & Kentucky & 36 & 0.99 \\
\hline Delaware & 37 & 0.42 & Utah & 37 & 1.25 \\
\hline Utah & 38 & 0.51 & South Dakota & 38 & 1.69 \\
\hline North Dakota & 39 & 0.59 & Arkansas & 39 & 1.88 \\
\hline Wisconsin & 40 & 0.60 & Rhode Island & 40 & 1.92 \\
\hline Arizona & 41 & 0.67 & Louisiana & 41 & 2.35 \\
\hline Hawaii & 42 & 0.78 & Maine & 42 & 2.67 \\
\hline Nebraska & 43 & 0.90 & Mississippi & 43 & 3.11 \\
\hline Illinois & 44 & 1.18 & Vermont & 44 & 4.53 \\
\hline Kansas & 45 & 1.21 & New Mexico & 45 & 4.74 \\
\hline Maryland & 46 & 1.53 & West Virginia & 46 & 4.75 \\
\hline Connecticut & 47 & 1.63 & North Dakota & 47 & 5.10 \\
\hline Nevada & 48 & 1.72 & Montana & 48 & 5.14 \\
\hline New Jersey & 49 & 2.26 & Wyoming & 49 & 11.56 \\
\hline (average) & & 0.03 & (average) & & 0.99 \\
\hline \multicolumn{4}{|c|}{ Note: Growth rates are (log) change in real personal income per capita over } & & \\
\hline \multicolumn{4}{|c|}{\begin{tabular}{|l|l} 
a five-year period. See text for explanation and discussion. & \\
\end{tabular}} & & \\
\hline
\end{tabular}



\begin{tabular}{|r|}
\hline Table 5 Effect of Incremental Taxes spent on Productive Services and \\
\hline Infrastructure on Growth in Real Personal Income Per Capita
\end{tabular}

\begin{tabular}{|l|l|l|}
\hline & & \\
\hline & Policy Experiment \#1: Incremental Taxes for
\end{tabular}
Productive Services/Infrastructure

\begin{tabular}{|c|c|c|}
\hline & & Incremental \\
\hline State & Ranking & Growth \\
\hline New York & 1 & -1.06 \\
\hline Wyoming & 2 & -0.65 \\
\hline Maine & 3 & -0.47 \\
\hline Hawaii & 4 & 0.00 \\
\hline Vermont & 5 & 0.06 \\
\hline Wisconsin & 6 & 0.07 \\
\hline Rhode Island & 7 & 0.16 \\
\hline Nebraska & 8 & 0.27 \\
\hline Ohio & 9 & 0.37 \\
\hline New Jersey & 10 & 0.38 \\
\hline New Mexico & 11 & 0.39 \\
\hline Kansas & 12 & 0.42 \\
\hline Connecticut & 13 & 0.43 \\
\hline West Virginia & 14 & 0.55 \\
\hline Louisiana & 15 & 0.55 \\
\hline California & 16 & 0.56 \\
\hline Minnesota & 17 & 0.59 \\
\hline Pennsylvania & 18 & 0.69 \\
\hline Michigan & 19 & 0.70 \\
\hline Utah & 20 & 0.72 \\
\hline Illinois & 21 & 0.75 \\
\hline Idaho & 22 & 0.79 \\
\hline Kentucky & 23 & 0.79 \\
\hline Maryland & 24 & 0.80 \\
\hline North Dakota & 25 & 0.80 \\
\hline Nevada & 26 & 0.81 \\
\hline Delaware & 27 & 0.82 \\
\hline Arizona & 28 & 0.86 \\
\hline Massachusetts & 29 & 0.87 \\
\hline North Carolina & 30 & 0.87 \\
\hline Mississippi & 31 & 0.88 \\
\hline Indiana & 32 & 0.90 \\
\hline Washington & 33 & 0.94 \\
\hline Iowa & 34 & 0.95 \\
\hline Florida & 35 & 0.95 \\
\hline Arkansas & 36 & 0.96 \\
\hline South Carolina & 37 & 0.97 \\
\hline Georgia & 38 & 1.04 \\
\hline Oklahoma & 39 & 1.06 \\
\hline Oregon & 40 & 1.10 \\
\hline Montana & 41 & 1.13 \\
\hline Texas & 42 & 1.19 \\
\hline Missouri & 43 & 1.25 \\
\hline Virginia & 44 & 1.26 \\
\hline Colorado & 45 & 1.50 \\
\hline South Dakota & 46 & 1.56 \\
\hline New Hampshire & 47 & 1.61 \\
\hline Tennessee & 48 & 1.64 \\
\hline Alabama & 49 & 1.69 \\
\hline (average) & & 0.72 \\
\hline
\end{tabular}

